\title{
Tanjungpinang City Tourism Development Strategy to Realize Halal Tourism
}

\author{
Dwi Vita Lestari Soehardi ${ }^{1}$, Atika Thaharah $^{2}$, Satriadi $^{3}$ \\ $\left\{\underline{\text { dwi_vita@stainkepri.ac.id }}{ }^{1}, \underline{\text { atikathahiraswim@ @mail.com }}^{2}, \underline{\text { satriadi@stie-pemhasilan.ac.id }}^{3}\right.$ \} \\ STAIN Sultan Abdurrahman Kepulauan Riau ${ }^{1}$, Raja Ali Haji Maritime University ${ }^{2}$, STIE \\ Pembangunan Tanjungpinang ${ }^{3}$
}

\begin{abstract}
Tanjungpinang City has potential to develop its tourism industry with locations such as Penyengat Island with the icon of the Sultan Riau Grand Mosque, the Tomb of the Kings and the Twelve Gurindam. However, from these attractions there are several problems related to halal tourism. However, there are several problems in Tanjungpinang related to halal tourism, namely, the minimal role of local governments in promoting halal tourism, the lack of community involvement in the development of tourism activities, and the decline in the number of tourist visits. The purpose of this study is to find the most appropriate strategy in developing Tanjungpinang City Tourism as a Halal Tourism Center in the Riau Islands Province. The results of this descriptive research will be beneficial for the Department of Culture and Tourism of the city of Tanjungpinang, leading to related parties making appropriate programs and policies. Realizing Tanjungpinang as a center of halal tourism would significantly improve the local economy. So, For the Tourism Development Strategy, this research covers the dimensions attractiveness, accessibility, security, public facilities (support services), and institutions. The research population is the Tanjungpinang community. The number of samples in this study was 3 resource persons consisting of an employees from the Tanjungpinang City Culture and Tourism Office, a member of Penyengat Island Community, and a Tourists. The sampling technique used by the author in this study is nonprobability sampling, combining purposive sampling and snowball sampling.
\end{abstract}

Keywords: Strategy, Tourism Development, Halal Tourism

\section{Introduction}

The country of Indonesia has the largest Muslim population in the world. Of course, this is a potential opportunity for the concept of combining tourism with Islamic sharia values. Halal tourism is the answer to the needs and desires of Muslim and non-Muslim tourists when making tourist visits. Indonesia is expected to become one of the countries in the world to offer halal tourism. Interestingly, countries with non-Muslim majority populations are the most active in providing halal tourism and implementing the concept of halal tourism. Global Muslim Travel is also one of the main targets of tourism programs developed by countries such as Japan, South Korea, China and Singapore. 
Table 1. Overall Top 10 Destinations by OIC and Non OIC in 2018

\begin{tabular}{clcclc}
\hline $\begin{array}{c}2017 \\
\text { Ranking }\end{array}$ & \multicolumn{1}{c}{ Country } & $\begin{array}{c}\text { Score } \\
(\%)\end{array}$ & $\begin{array}{c}\text { Ranking } \\
2018\end{array}$ & Country & $\begin{array}{c}\text { Score } \\
(\%)\end{array}$ \\
\hline 1 & Malaysia & 82.50 & 1 & Malaysia & 80.6 \\
2 & United Arab Emirates & 76.90 & 2 & Indonesia & 72.8 \\
3 & Indonesia & 72.60 & 3 & United & Arab \\
& & & Emirates & \\
4 & Turkey & 72.40 & 4 & Turkey & 69.1 \\
5 & Saudi Arabia & 71.40 & 5 & Saudi Arabia & 68.7 \\
6 & Qatar & 70.50 & 6 & Qatar & 66.2 \\
7 & Morocco & 68.10 & 7 & Bahrain & 65.9 \\
8 & Oman & 67.9 & 8 & Oman & 65.1 \\
9 & Bahrain & 67.9 & 9 & Morocco & 61.7 \\
10 & Iran & 66.8 & 10 & Kuwait & 60.5 \\
\hline
\end{tabular}

Source: Global Muslim Travel Index 2018

The efforts of the Indonesian state in improving the performance of 10 leading Muslimfriendly tourist destinations have resulted in achievements with Indonesia being the best Muslim-friendly tourist destination in the world according to the Global Muslim Travel Index (GMTI) standards in 2019. This achievement is expected to invite global tourists to visit Indonesia. Since March 2020, the Covid-19 pandemic has had a significant impact on the tourism sector, including the Muslim-friendly tourism industry (KNEKS, 2020).

The archipelago province of the Riau Islands is in a strategic location, , namely as a border area close to the neighboring countries of Singapore and Malaysia. The total area of the Riau Islands Province is $251,810.71 \mathrm{Km}^{2}$, consisting of a sea area of $241,215.30 \mathrm{Km}^{2}$ $(95.79 \%)$ and a land area of $10,595.41 \mathrm{Km}^{2}(4.21 \%)$. The Riau Archipelago is recognized as having great potential to become a center for national halal tourism, because it is supported by natural beauty, cultural diversity and a dominant Muslim population. Likewise, Tanjungpinang City has unique attractions for foreign tourists such as Penyengat Island which has historical sites of the Sultanate of Johor-Riau-Pahang-Lingga. This is particularly appealing for Malaly tourists from Malaysia and Singapore as they are able to reminisce the glory of the Malay Sultan.

There have been many promotional and marketing efforts carried out by the Ministry of Tourism in promoting regions in Indonesia as halal tourism destinations. However, it is important to consider that the development of halal tourism is not only carried out in order to pursue a certain position globally but also must be supported by policies focusing on economic growth and development.

Halal tourism policies/regulations would build awareness for local governments and related business actors and provide them with guidance in developing to meet the requirements of Muslim tourists. Currently, the weakness in halal tourism in Indonesia is that there are no specific guidelines at the provincial and district/city levels for developing halal tourism. The fulfillment of the needs and desires of Muslim tourists is the application of the principles of responsible tourism development.

\section{Literature Review}

The definitions of tourism have been standardized into a law, namely Law no. 10 of 2009 concerning tourism, what is meant by tourism is various kinds of tourism activities that 
are supported by various facilities and services provided by the community, entrepreneurs, the Central Government and Regional Governments. Tourism is an activity that is carried out differently from daily activities. People who carry out tourist activities are usually referred to as tourists. Tourists are an important element in tourism because without tourists, tourism objects will not function.

Tourism is a planned change in a person's temporary residence outside their place of residence and not for the purpose of carrying out activities that generate wages. Thus, it can be said that tourism is the journey undertaken by one or more persons for pleasure and the desire to learn as well as interests related to sports activities for health (Ali, 2015)

Irawan, 2010 defines words related to tourism as follows:

1. Tourism: Travel, in English is called "Travel".

2. Tourism: Travel from one place to another, is called a "tour".

3. Tourists: People who travel are called Tourists

4. Tourism: Things related to tourism and in English it is called "Tourism".

Places that are used as tourist destinations are called tourist objects. Tourist attractions are divided into three types as follows:

1. Natural tourism objects, including mountainous landscapes, nature reserves, lakes, beaches, volcanic craters, hot springs, flora and fauna.

2. Recreational tourism objects, including slide pools, swimming pools, reservoirs, and recreational parks.

3. Cultural tourism objects, including ancient forts, ancient mosques, ancient churches, museums, palaces, monuments, temples, regional arts, traditional houses, and traditional ceremonies.

In simple terms, halal tourism is tourism that is aimed at Muslim tourists. Halal tourism provides access and facilities that offer convenience for Muslims to carry out worship activities. Additionally, halal tourism safeguards Muslims from various activities and consumptions that are prohibited by Islamic law.

Sharia Tourism or Halal Tourism is one of the tourism systems intended for Muslim tourists which complies with Sharia rules. For example, hotels that follow sharia principles do not serve alcoholic beverages and have separate swimming pools and spa facilities for men and women. Sharia tourism prioritizes halal products and are safe for Muslim tourists to consume. However, this does not mean that non-Muslim tourists cannot also enjoy sharia tourism.

Halal tourism as a new trend that is growing in the world of tourism and is referred to by several terms around the world, such as Islamic Tourism, Halal Friendly Tourism Destinations, Halal Travel, Muslim Friendly Travel Destinations and halal lifestyle destination,. Halal is synonymous with Clean, Comfortable, Orderly and Healthy. Halal is a universal term and adds tourism value. The development of halal tourism requires serious efforts from the various actors involved, ranging from regulation, management, infrastructure to the community around tourist destinations.

\subsection{Characteristics of Halal Tourism}

According to Chukaew (2015) there are eight standard factors for measuring halal tourism in terms of administration and management, namely: 
1) Service to tourists must be in accordance with Muslim principles as a whole,

2) Guides and staff must be disciplined in and respect Islamic principles,

3) Regulation of all activities so as not to conflict with Islamic principles,

4) Buildings must comply with Islamic principles,

5) Restaurants must comply with international standards of halal service,

6) Transportation services must have a security protection system,

7) There are places provided for all Muslim tourists to carry out religious activities.

8) Traveling must be to places that are not against Islamic principles.

Table 2. Comparison of Conventional Tourism, Religious Tourism and Halal Tourism

\begin{tabular}{|c|c|c|c|c|}
\hline No & Comparison Items & Conventional & Religious & Sharia \\
\hline 1 & Attraction & $\begin{array}{l}\text { Nature, Culture, } \\
\text { Heritage, Cuisine }\end{array}$ & $\begin{array}{l}\text { Places of Worship, } \\
\text { Historical Heritage }\end{array}$ & $\begin{array}{l}\text { Nature, Culture, } \\
\text { Heritage, Cuisine, } \\
\text { Places of Worship, } \\
\text { Historical Heritage }\end{array}$ \\
\hline 2 & Aim & Entertainment & Increase spirituality & $\begin{array}{l}\text { Increase spirituality } \\
\text { through } \\
\text { entertainment }\end{array}$ \\
\hline 3 & Target & $\begin{array}{l}\text { To provide enjoyable } \\
\text { entertainment. }\end{array}$ & $\begin{array}{l}\text { Utilizing spiritual } \\
\text { locations to calm the } \\
\text { soul and find inner } \\
\text { peace. }\end{array}$ & $\begin{array}{lr}\text { Fulfilling desires and } \\
\text { pleasures } & \text { while } \\
\text { fostering } & \text { religious } \\
\text { awareness. } & \end{array}$ \\
\hline 4 & Guide & $\begin{array}{ll}\text { Acquiring } & \text { and } \\
\text { understanding } & \\
\text { information } & \text { to } \\
\text { attract tourists } & \text { to } \\
\text { tourism objects } & \end{array}$ & $\begin{array}{l}\text { Knowledgeable about } \\
\text { the history of figures } \\
\text { and locations that are } \\
\text { tourist attractions }\end{array}$ & $\begin{array}{l}\text { Making tourists } \\
\text { interested in the } \\
\text { attraction as well as } \\
\text { awakening their } \\
\text { religious spirit. Able } \\
\text { to explain the } \\
\text { function and role of } \\
\text { halal in the form of } \\
\text { happiness and inner } \\
\text { satisfaction in human } \\
\text { life }\end{array}$ \\
\hline 5 & Worship Facilities & Just a complement & Just a complement & $\begin{array}{l}\text { An integral part of } \\
\text { tourist attractions. } \\
\text { Worship rituals are } \\
\text { part of the } \\
\text { entertainment } \\
\text { package. }\end{array}$ \\
\hline 6 & Cuisine & General & General & Halal specific \\
\hline 7 & $\begin{array}{l}\text { Relations with the } \\
\text { Community in the } \\
\text { Tourism Object }\end{array}$ & $\begin{array}{l}\text { Complementary and } \\
\text { only for material gain }\end{array}$ & $\begin{array}{l}\text { Complementary and } \\
\text { only for material gain }\end{array}$ & $\begin{array}{l}\text { Integrated. } \\
\text { Interaction is based } \\
\text { on Sharia principles }\end{array}$ \\
\hline 8 & Travel Planner & Available any time & $\begin{array}{l}\text { Available at certain } \\
\text { times }\end{array}$ & Pays attention to time \\
\hline
\end{tabular}

Source: Ngatawi Al Zaztrow in Hamzah and Yudiana, 2015(Tourism, 2015)

Mason (2000:46) and Poerwanto (1998:53) have identified the components of tourism products,: 
1. Attractions, namely natural, cultural or man-made tourist attractions such as festivals or art performances

2. Accessibility, namely the ease of obtaining or achieving tourist destinations such as tourism organizations (travel agents)

3. Amenities, namely facilities that provide comfort. In this case it can take the form of accommodation, cleanliness and hospitality

4. Networking, namely a network of cooperation among actors related to the products offered both locally, nationally and internationally.

\section{Research Methodology}

This research uses an exploratory method with a qualitative-descriptive approach to highlight the potential for halal tourism in Tanjungpinang City an instrument to attract Muslim tourists.

According to Arikunto (2010) exploratory research seeks to explore the causes or things that influence the occurrence of something. Exploratory research also seeks to explore new knowledge to find a problem.

Exploratory research aims to understand the cause of a problem, particularly for new problems where there is limited existing research.

This study seeks to identify strategies in tourism development with the aim of realizing Tanjungpinang City as a center for halal tourism in the Riau Islands. The informants in this study were three resource persons consisting of an employee of the Tanjungpinang City Culture and Tourism Office, a Tanjungpinang City resident, and Tourist. The sampling technique used by the author in this study is non-probability sampling. For this research, primary data was collected from academic books, journals, reports, official news and press releases (as well as the secondary data sourced from the internet.) The stages of this research are data collection, presenting data in the form of narratives and tables, and drawing conclusions.

\subsection{Discussion of Results}

In tourism development, planning must be carried out thoroughly, so that optimal benefits can be obtained for the community, from economic, social and cultural perspectives. The plan must integrate tourism development into a country's economic, physical and social development program. In Law R1 No. 10 of 2009 Articles 6 and 7, concerning tourism development, it is stated that tourism development must pay attention to diversity, uniqueness and uniqueness of culture and nature as well as human desire for tourism (Article 6). Tourism development includes the tourism industry, tourism destinations, marketing and tourism institutions (Article 7).

Tourism development is essentially a process in order to improve and enhance something that already exists. Tourism development can be in the form of developing activities, the maintenance and preservation of plants, facilities and infrastructure. Tourism development is also a community and regional development activity based on:

1. Advancing people's standard of living while maintaining local identity.

2. Increasing the level of income economically and equally in the community.

3. Oriented to the development of small and medium scale tourism with a large 
employment absorption and oriented to cooperative technology.

4. Utilizesing tourism as optimally as possible as a contributor to the country's traditions.

5. Cultivate a sense of love for the homeland and maintain the nation's identity.

Tourism can only be developed using certain strategies. such as the SWOT analysis method. SWOT is a very common method and is widely used in all aspects of business development including tourism. This strategy is carried out by evaluating the strengths, weaknesses, opportunities and threats in a project. SWOT is an effective and efficient analytical tool in finding possibilities related to the initial development of new innovation programs in the tourism sector.

The use of SWOT analysis in tourism development scenarios is as follows:

Table 3 Tanjungpinang City Halal Tourism SWOt Analysis

\begin{tabular}{|c|c|c|}
\hline & Strengths & Weaknesses \\
\hline $\begin{array}{l}\text { Destinations for } \\
\text { Halal Tourism }\end{array}$ & $\begin{array}{l}\text { 1. Tanjungpinang is in close proximity } \\
\text { to the Sultan Mosque of Penyengat } \\
\text { Island. } \\
\text { 2. Tanjungpinang is rich in culture and } \\
\text { cultural heritage. } \\
\text { 3. Local people are hospitable. } \\
\text { 4. Tanjungpinang is a pilot project for } \\
\text { the development of halal tourism in } \\
\text { Tanjungpinang, Riau Islands. } \\
\text { 5. Attractions are easily accessible } \\
\text { (the airport, port and roads are } \\
\text { satisfactory) }\end{array}$ & $\begin{array}{l}\text { 1. Not many food and drink outlets } \\
\text { have halal certification. } \\
\text { 2. There is a lack of use of } \\
\text { technology in making } \\
\text { information easily accessible for } \\
\text { Muslim tourists. } \\
\text { 3. There is no policy that regulates } \\
\text { halal tourism guidelines. } \\
\text { 4. There is a lack of halal tourism } \\
\text { promotion. } \\
\text { 5. The HR management system is } \\
\text { not yet optimal. }\end{array}$ \\
\hline $\begin{array}{l}\text { Destinations } \\
\text { Tourist } \\
\text { Halal }\end{array}$ & 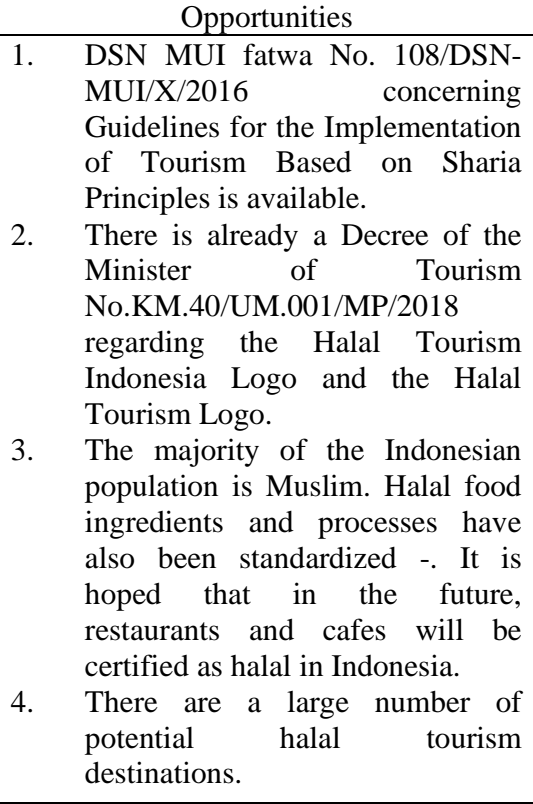 & $\begin{array}{l}\text { Threats } \\
\text { 1. Lack of quality human } \\
\text { resources who understand } \\
\text { Sharia }\end{array}$ \\
\hline
\end{tabular}

Source: Research Results, 2021. 
Tanjungpinang is currently one of the favorite tourist destinations. The development of tourism potential, tourism promotion and infrastructure in the tourism sector would attract both domestic and foreign tourists to visit Tanjungpinang City. Tourism in Tanjungpinang City is also supported by various tourism potentials ranging from natural tourism to its distinctive culture. According to Shakiry, "The concept of sharia tourism is not limited to religious tourism, but extends to all forms of tourism except those that are contrary to Islamic values."

To develop halal tourism in Tanjungpinang City, several special strategies are needed. The Tanjungpinang City government has previouslycarried out tourism promotion using print media and the use of external media with a program of installing billboards, banners, posters and billboards containing the schedule for each event held.The events held to develop halal tourism in Tanjungpinang City are Stinging Island Festival, Art Tools, Ramadan Festival, Takbir Ornamental Car Parade, Semprong Cake Festival, Serantau Syawal Festival, Art Devices, Tanjungpinang Children's Festival, Riau Islands Maritime Festival, Carang River Festival, Kampoeng Tanjungpinang Kite Festival, New Year Celebration, Manuk Hill Festival and Gonggong Festival.

One aim of tourism is to make tourists feel welcome at tourist destinations. Halal is not just a word but has a very deep meaning with regards to Islamic principles and values. When the halal standards are not fully implemented, members of the Tanjungpinang community and tourists especially, feel anxious.

Based on the research results, "halal" branding is the main choice for Tanjungpinang tourism branding compared to the use of "Syariah" branding, or "Islamic Tourism". If Islamic branding is used, it is feared that it will lead to the Islamaphobia and that the elimination of the halal concept will only revive conventional tourism. I In addition to halal branding, Tanjungpinang also uses the branding "Culture-Based Tourism Destinations" which is very closely related to Halal branding. Thus everything from food products to facilities and infrastructure must be in accordance with Islamic principles and values.

In the development of halal tourism, the main paradigm that needs to be understood is that halal tourism does not aim to alienate Muslim tourists from general tourism activities or to limit non-Muslim tourists to certain tourist destinations. religious law when traveling.

\section{Conclusion}

Based on the results of the research, the strategy for developing halal tourism in Tanjungpinang is as follows:

1. Making tourism a leading sector;

2. Implementing an integrated movement for tourism development;

3. Coordinating Meetings with Provincial Government, City/Regency Government and Stakeholders

4. Making Tanjungpinang a National Halal Destination;

5. Making Tanjungpinang a National Halal Culinary Destination;

6. Offering Halal Tourism Socialization for Tourism Stakeholders;

7. Invigorating the promotion of halal tourism by digitalization;

8. Proviingd subsidies for the management of Halal Certification for industries 
(restaurants/cafes);

9. Preparating Regional Regulations on Halal Tourism.

\section{References}

[1] Ali, Hasan. 2015. Tourism Marketing. Center for Academic Publishing Service. Yogyakarta.

[2] Arief, Muhammad. (2018). AnalisisRekrutmen dan Penempatan Kerja terhadap Kinerja Karyawan pada Hotel Oase. Jurnal Al-Hikmah: Vol. 15 (1): 42-63.

[3] Bungin, Burhan, Metodologi Penelitian Sosial, Surabaya :Airlangga University Press. 2004

[4] Dalyo. (2012). Kualitas SDM Pariwisata: Era Otda dan Globalisasi. Jakarta: Pustaka

[5] Durkin, J dan Peric, M. (2017). Menyelenggarakan Pariwisata Berbasis Masyarakat: Membandingkan Sikap Penduduk Lokal dan Pengusaha Pariwisata Lokal di Ravna Gora. Ekonomilokal.

[6] Fahad Salim Bahammam, Panduan Wisatawan Muslim. Jakarta : Pustaka AlKautsar. 2012 Hadiwijoyo, Suryo Sakti. (2012). Perencanaan Pariwisata Pedesaan Berbasis Masyarakat (Sebuah Pendekatan Konsep). Yogyakarta :Graha Ilmu

[7] Hamzah, Maulana. M dan Yudiana, Yudi. (2015). Analisis Komparatif PotensiIndustri Halal dalam Wisata Syariah dengan Konvensional.

[8] Irawan, Koko. 2010. Potensi ObjekWisata Air Terjun Serdang Sebagai Daya Tarik Wisata Di Kabupaten Labuhan Batu Utara. Kertas Karya. Program Pendidikan Non GelarPariwisata. Universitas Sumatera Utara.

[9] Kemenpar,2018. Desain Strategi dan Rencana AksiProvinsi Nusa Tenggara Barat Tahun 2018 - 2019

[10] Kotler, Philip, dan Kevin L. Keller. (2009). Manajemen Pemasaran jilid 1. Alih Bahasa: Benyamin Molan. Edisi Ketiga Belas. Alih Bahasa : Bob Sabran. Jakarta: Erlangga.

[11] Kotler, Philip, dan Kevin L. Keller. (2009). Manajemen Pemasaran jilid 2. Alih Bahasa: Benyamin Molan. Edisi Ketiga Belas. Alih Bahasa : Bob Sabran. Jakarta: Erlangga.

[12] Kristiningrum, Nur Dwi. (2014). Heritage Tourism dan Creative Tourism: Eksistensi Pasar Seni (Central market) di Malaysia sebagai salah satu pasar bersejarah. Jurnal Hubungan Internasional tahun VII, No.1 Januari-Juni 2014.

[13] KNEKS (2020). Laporan Perkembangan Pariwisata Ramah Muslim Daerah 20192020.

[14] Global Muslim Travel Index (GMTI). 2016. Kempar. Jumlah Kunjungan Wisatawan Mancanegara Menurut Pintu Masuk dan Kebangsaan. Jakarta : Kementerian Pariwisata

[15] Kuncoro, Mudjarad. (2007). Metode Kuantitatif Teori dan Aplikasi untuk Bisnis dan Ekonomi. Yogyakarta : IPD STIM YKPN.

[16] Moleong, Lexy.J. (2005). Metodologi Penelitian Kualitatif, Bandung :Remaja Rosdakarya.

[17] Pariwisata, Kementerian. 2015. Laporan akhir kajian pengembangan wisatasyariah.

[18] Sofyan, Riyanto. Prospek Bisnis Pariwisata Syariah. Jakarta: Republika. 2012

[19] Suharso, Puguh, Model Analisis Kuantitatif. Jakarta: Indeks. 2010 
[20] Sunaryo, Bambang. (2013). Kebijakan Pembangunan Destinasi Pariwisata Konsep dan Aplikasinya di Indonesia. Yogyakarta :Gava Media.

[21] Unggul Priyadi. 2016. Pariwisata Syariah- Prospek dan Perkembangan. UPP STIM YKPN. Yogyakarta.

[22] UU No. 10 tahun 2009 tentang Kepariwisataan, 